\title{
The Effectiveness of Learning English Using LMS Google Classroom during Covid-19 Pandemic
}

\author{
Muhammad Taufik1, Andi Samsu Rijal'2, Dahniar3, Eka Apriani4
}

DOI: $10.35445 /$ alishlah.v13i2.706

\begin{tabular}{l}
\hline Article Info \\
\hline Keywords: \\
Covid-19; \\
English Learning; \\
Google Classroom; \\
Learning Management \\
System
\end{tabular}

Kata kunci:

Covid-19;

Pembelajaran Bahasa

Inggris;

Google Classroom;

Sistem Manajemen

Pembelajaran

\begin{abstract}
This study aimed to determine how Google Classroom enhanced English language learning in students' English at the Faculty of Literature and Humanities in the online learning system during the Covid-19 pandemic. This research was a classroom action research (CAR) conducted from March to July 2020. Classroom action research consists of four stages; planning, actions, observation, and reflection. It is better to fix this section as follows: The stage; teacher planning (preparation and pre-test), action (teaching by using Google Classroom), observation (Classroom observation), and reflection (personal reflection and post-test). The features of LMS Google Classroom promote the development of independent learners in which students can be triggered to access the information in any place and time. This research shows that the LMS Google Classroom learning model is considered an effective learning model to enhance independent learning. Data of the Speaking test has described in finding that there is significance increasing from pre-test to post-test. The score increased from 1103 in the pre-test to 1618 in the post-test. It shows an increase in mean score from 36.7667 in the pre-test to 54.1467 in the post-test. ELearning is running well, especially for speaking classes. By using LMS Google Classroom in English teaching can help students to improve their English skills. Teaching English by implementing Learning Management System Google Classroom at the university can effectively improve students' English competency, where almost all students agree to this point. Twenty-five students agreed that this learning model could improve the students' competencies, and only one student disagrees. For speaking teaching that some of the students disagree with using LMS Google Classroom, six students gave a negative response, and 24 agreed. The analysis results showed that the English Literature Study Program students at the Islamic University of Makassar responded well when their lecturer used LMS Google Classroom in the learning process.
\end{abstract}

\begin{abstract}
Abstrak
Penelitian ini bertujuan untuk mengetahui bagaimana Google Classroom bekerja untuk meningkatkan efektivitas pembelajaran bahasa Inggris pada mahasiswa Fakultas Sastra dan Humaniora dalam sistem pembelajaran online selama pandemi Covid-19. Penelitian ini merupakan penelitian tindakan kelas (PTK) yang dilaksanakan pada bulan Maret hingga Juli 2020. Penelitian tindakan kelas terdiri dari empat tahap; perencanaan, tindakan, observasi, dan refleksi. Perencanaan (persiapan dan pre-test), tindakan (mengajar dengan
\end{abstract}

\footnotetext{
${ }^{1}$ UIM Makassar, Sulawesi Selatan, Indonesia

Email: muhammadtaufik.dty@uim-makassar.ac.id

${ }^{2}$ UIM Makassar, Sulawesi Selatan, Indonesia

Email: andisamsurijal.dty@uim-makassar.ac.id

3UIM Makassar, Sulawesi Selatan, Indonesia

Email: dahniar.dty@uim-makassar.ac.id

4IAIN Curup, Bengkulu, Indonesia

Email: eka.apriani@iaincurup.ac.id
} 
menggunakan Google Classroom), observasi (pengamatan Kelas), dan refleksi (refleksi pribadi dan post-test). Fitur LMS Google Classroom digunakan untuk mendorong pengembangan pembelajar mandiri dimana siswa dapat terpicu untuk mengakses informasi di mana saja dan kapan saja. Hasil penelitian menunjukkan bahwa model pembelajaran LMS Google Classroom dianggap sebagai model pembelajaran yang efektif sebagai sarana dalam meningkatkan kemandirian belajar. Data tes Berbicara telah dijelaskan dalam menemukan bahwa, ada peningkatan signifikan dari hasil pre-test ke post-test. Skor tersebut meningkat dari 1103 pada pre-test menjadi 1618 pada post-test. Hal ini menunjukkan adanya peningkatan nilai rata-rata dari 36,7667 pada pre-test menjadi 54,1467 pada post-test. E-Learning berjalan dengan baik terutama untuk kelas berbicara, dengan menggunakan LMS Google Classroom. LMS Google Classroom dalam pengajaran bahasa Inggris dapat membantu siswa untuk meningkatkan kemampuan bahasa Inggris. Mengajar Bahasa Inggris dengan menerapkan Learning Management System Google Classroom di Universitas dapat secara efektif meningkatkan kompetensi bahasa Inggris siswa" di mana hampir semua siswa setuju dengan hal ini. Terdapat 25 siswa yang setuju bahwa model pembelajaran ini dapat meningkatkan kompetensi siswa dan hanya satu siswa yang tidak setuju. Untuk pembelajaran berbicara yang sebagian siswanya tidak setuju jika menggunakan LMS Google Classroom, terdapat 6 siswa yang memberikan respon negatif dan 24 siswa di antaranya setuju. Hasil analisis tersebut menunjukkan bahwa mahasiswa Program Studi Sastra Inggris Universitas Islam Makassar merespon dengan baik penggunaan LMS GC dalam pembelajaran bahasa Inggris.

\section{INTRODUCTION}

The Government of the Republic of Indonesia, through the Minister of Education and Culture, has issued circular number 4 of 2020 concerning the implementation of education in the emergency period of the spread of Covid-19. The teaching and learning process is carried out from home or online teaching f (Nusantari, Sumarwati, \& Anindyarini, 2020). The implementation of online teaching or E-Learning has created a new model of communication and interaction by utilizing technological media (Oliveira et al., 2016). So far, online teaching at tertiary institutions in Indonesia has been going.

The online teaching and learning activities have been run for three semesters. But in this online teaching, students face various obstacles, both in terms of the readiness of facilities and infrastructure, learning achievement, and students' attitudes. According to Kuntarto E. (2017), there are differences in students' perceptions and attitudes in implementing E-Learning in higher education, especially since this learning method is relatively new in Indonesia. Furthermore, Bellou et al. (2018) portray that these perceptions and attitudes are caused by different learning outcomes, teaching materials, teaching methods, and learning technologies implemented.

Language teaching using the E-Learning method requires strategies, appropriate materials, learning tools, and different levels of competency achievement. In the Covid-19 pandemic, this greatly impacts the social situation of the community, such as social restrictions, maintaining distance, and requiring work from home (Abdullah, 2020). This social situation complicates language teaching patterns, not only on competence but also on material realization points, which is very different when done with offline learning. The presence of various learning facilities such as the Learning Management System (LMS) makes it easy for teachers with various meeting facilities, student monitoring, and online communication processes so that face-to-face online learning can take place (Abushawar \& Al-Sadi, 2010). According to Cavus (2015), his experience (2015) in applying LMS to distance teaching, communication between teachers and students can run well because LMS already has various features supporting teaching. LMS does not replace traditional classroom systems, but they supplement the classroom with course content accessed from the Internet. According to Bradford (2011), the various educational software applications have substantially enhanced student motivation and have encouraged feedback. Currently, most learning 
facilities utilize the LMS as a tool for instruction delivery in traditional classroom setups. The software applications also provide students with additional information since they incorporate numerous learning resources that might not be available in traditional educational materials.

Furthermore, Bradford, G. R. (2011) explains a relationship study of student satisfaction with learning online and cognitive load: Initial $\mathrm{r}$ Learning management system (LMS) is software designed to create, distribute, and organize learning content. This system can help teachers plan and create a syllabus, manage learning materials, manage students' learning activities, manage grades, emulate students' attendance, display transcripts of grades, and manage e-learning views.

Google Classroom is a learning management system that can provide teaching materials and integrated assessment tests. In contrast to other learning media, the advantages of google classroom media are a matter of effectiveness and efficiency in learning. Google Classroom is a google product that connects with Gmail, drive, hangout, YouTube, and calendar events. The many facilities provided by google classroom will make it easier for teachers to carry out learning activities. The learning in question is not only in the classroom but also outside the classroom because students can do learning anywhere and anytime by accessing google classroom. This application can operate effectively, assisting lecturers and students enrolled in English language education study programs in carrying out the learning process more intensely.

\section{METHODS}

This research used mixed methods. Mixed methods is a research approach whereby researchers collect and analyze quantitative and qualitative data within the same study. Mixed methods research requires a purposeful mixing of data collection, analysis, and interpretation of the evidence.

\section{A questionnaire for students need analysis}

The questionnaire is used to carry out students' need analysis in order to get information or data from students about their opinion on the present situation of general English course existing materials used by their teachers and to identify the students' needs and expectations toward the material of English speaking course in an online class by google classroom that in line with their needs.

\section{A questionnaire for students' opinion toward learning English through web-based instruction}

The questionnaire is used to find out students' perceptions and opinions and comment on the effectiveness of the speaking materials that learn by google classroom to promote students' independent learning performance. The researcher provided an evaluation form for the lecturers to determine their responses toward the prototype draft of the web-based instructional materials that the researcher had developed. There are 4 (four) indicators with each component: the appropriateness of contents, language, presentation, and graphics.

Data analyzed in this study were the results of the English teaching test using the LMS Google Classroom method and the results of a questionnaire distributed to 30 respondents as a sample. The test results in question compare the pre-test scores before the trial of teaching English using the LMS Google Classroom with the post-test scores after teaching English using the LMS Google Classroom.

The design of this study was quantitative research. The researchers collected data by disseminating questionnaires to 30 students of the English Department of the Islamic University of Makassar, Indonesia, who participated by snowball sampling technique. The research collected data by employing a questionnaire in Google form and sharing it through Whatsapp. The descriptive statistics analyzed the data.

According to Creswell (2014), exploration activities in research attempt to understand the meaning of individuals and groups. This research is applied research that seeks to solve teaching problems, and student needs in learning English and implement appropriate strategies in applying E-Learning with LMS in the English Literature Study Program, Faculty of Literatures and 
Humanities (FSH), Islamic University of Makassar. This study uses a contextual learning approach while implementing the LMS Google Classroom adopts a theoretical framework conceptualized by Lewis and Whitlock (Abubakar \& Hassan, 2013). In the concept developed by Lewis and Whitlock, the first step that must be taken is to identify E-Learners (Mathar, Akbar, \& Arifin, 2020). A classroom action research, Classroom Action Research (CAR), is research conducted by a teacher (educator) in a classroom or place where he teaches focused on improving the learning process and action. Class Action Research serves as a tool to solve problems that arise in the classroom and also as a tool for in-service training, where teachers use new skills and methods and sharpen their analytical abilities. Furthermore, as a tool to create innovative learning, as a tool to improve communication between teachers and scientific researchers, and a tool that provides alternatives to problems that occur in the classroom. CAR is conducted through a cycle consisting of four stages: action planning, learning actions and observation activities, and reflection to analyze data obtained through action.

Classroom Action Research is a method of finding out what works best in your own classroom to improve student learning. We know a great deal about good teaching in general (e.g., McKeachie, 1999; Chickering and Gamson, 1987; Weimer, 1996), but every teaching situation is unique in terms of content, level, student skills and learning styles, teacher skills, and teaching styles, and many other factors. To maximize student learning, a teacher must find out what works best in a particular situation.

\section{FINDINGS AND DISCUSSION}

\section{Findings}

The LMS Google Classroom learning model was implemented to implement the teaching and learning process during the Covid-19 pandemic. The emergence of E-Learning has a significant impact on education, including the English teaching and learning process. The various stages in this research include preparing teaching materials, determining the test class and respondent, pre-test, implementing English teaching using the LMS Google Classroom model, class observation, post-test, giving questionnaires, data collection, and data analysis.

From the results of teaching English with the LMS Google Classroom, several lecturers who teach courses included Listening Comprehension I, Speaking I, Grammar \& Structure I, and Reading Comprehension I, and Writing I courses. Throughout the semester, you will be learning, practicing, and developing two skill components: speaking skill components and pronunciation skill components. Speaking skill components include basic communicative skills in English such as greeting, self-introduction, and saying goodbye. Meanwhile, pronunciation skill components consist of basic pronunciation patterns of English, such as word stress and sentence intonation courses, and so on are practical courses with an online system. The average duration of online meetings is 10-12 grade face-to-face and $4 \mathrm{X}$ face-to-face, then assignments and exams. The time efficiency used is 100 minutes, including preparation for login, attendance, lecture materials, and discussions. The implementation of LMS Google Classroom in English teaching at the English Literature Study Program, Faculty of Literature and Humanities, Islamic University of Makassar, is running effectively, despite obstacles in E-Learning.

The method stages of this research include the preparation of teaching materials, the readiness of teaching facilities and infrastructure, the readiness of participants (students) both in terms of learning facilities such as laptops, cell phones, Internet access, and the LMS Google Classroom application device. The test results show an increase from the pre-test to the post-test results even though the increase is not so significant. The teaching materials via google classroom week by week. The participant/student may also download the materials via Google Drive. To avoid the student cellphone data charges, we use a Wi-Fi connection available for free on campus or coffee shops to download the materials. 
The weekly teaching materials for the Speaking and Pronunciation components will consist of Audio and Text/Transcript items. The following table shows the score of students' pre-test before treatment.

Table 1. The Students' pre-test score in Speaking I Class before Treatment

\begin{tabular}{cccc}
\hline Classification & $\begin{array}{c}\text { Average } \\
\text { Score }\end{array}$ & Frequency & Percentage \\
\hline Very good & $80-100$ & - & 0,0 \\
\hline Good & $70-79$ & 1 & 3,3 \\
\hline Acceptable & $60-69$ & 3 & 10 \\
\hline Poor & $50-59$ & 1 & 3,3 \\
\hline Very poor & $0-49$ & 25 & 83,4 \\
\hline & & 30 & 100,0 \\
\hline
\end{tabular}

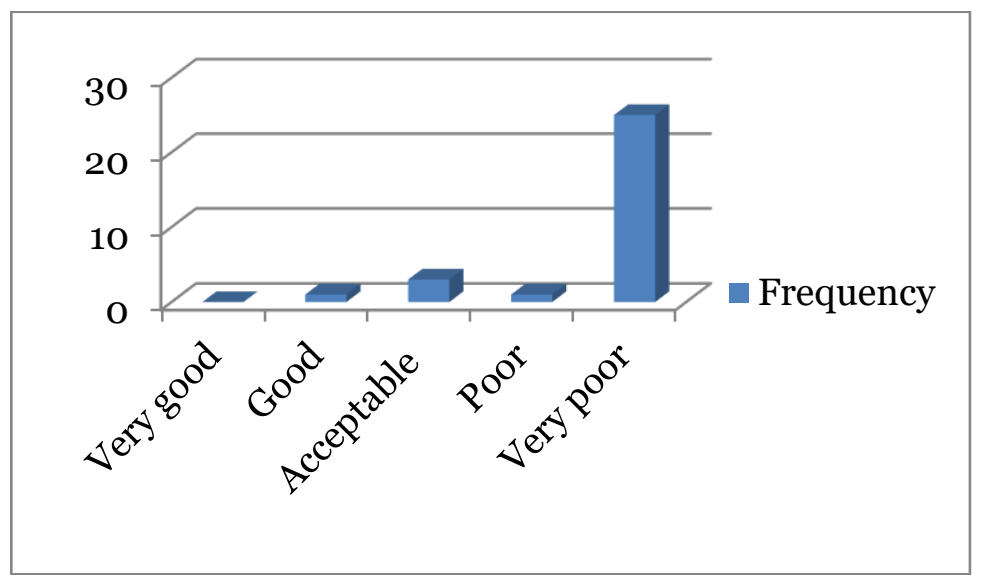

Figure 1. The students' pre-test score

The table and figure above show students' pre-test score before treatment, in which there was $1(3.3 \%)$ in a good score, 3 (10 \%) fair score, 1 (3.3\%) poor score, and 25 (83.4\%) very poor score. It can be seen from these pre-test results that students' mean score of pre-test result was in the very poor category.

Table 2. The Students post-test Score in Teaching Speaking I using LMS Google Classroom

\begin{tabular}{cccc}
\hline $\begin{array}{c}\text { Classification } \\
\text { Score }\end{array}$ & $\begin{array}{c}\text { Average } \\
\text { Score }\end{array}$ & $\begin{array}{c}\text { Frequen } \\
\text { cy }\end{array}$ & Percentage \\
\hline Very good & $80-100$ & - & 0,0 \\
\hline Good & $70-79$ & 4 & 13,3 \\
\hline Acceptable & $60-69$ & 7 & 23,3 \\
\hline Poor & $50-59$ & 11 & 36,7 \\
\hline Very poor & $0-49$ & 8 & 26,7 \\
\hline & & 30 & 100,0
\end{tabular}




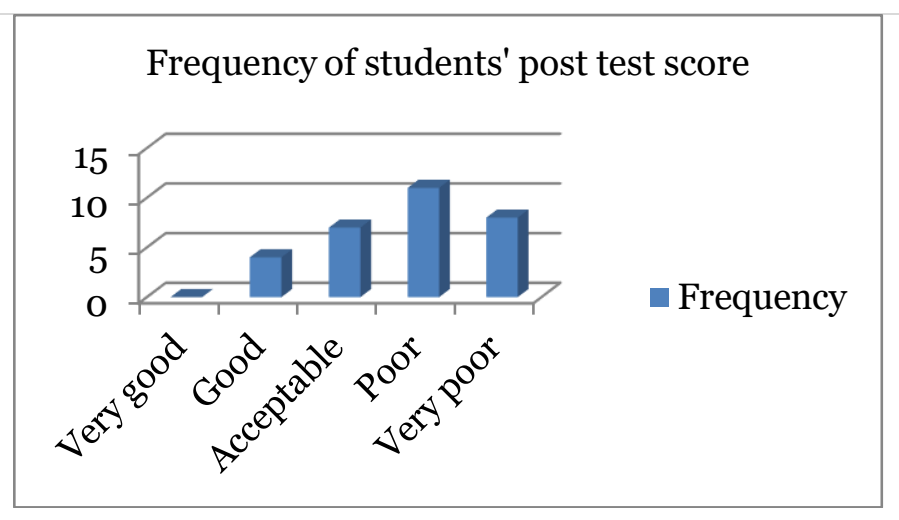

Figure 2. The students' post-test score

The table and figure above show the frequencies of students' scores after treatment increased even though no student got good to excellent (very good) score. There were 4 (13.3\%) of respondents who got a good score, 7 (23.3\%) of respondents got a fairly good (acceptable) score, 11 (36.7\%) of respondents got a poor score, and $8(26,7 \%)$ of respondents got the very poor score.

\section{Table 3. The Overall of Students' Score in Teaching Speaking I using LMS Google Classroom

\begin{tabular}{ccccc}
\hline & \multicolumn{2}{c}{ Pre Test } & \multicolumn{2}{c}{ Post Test } \\
\cline { 2 - 5 } & Total & Mean & Total & Mean Score \\
& Score & Score & Score & \\
\hline Speaking I & 1103 & 36,7667 & 1618 & 54,1467 \\
\hline
\end{tabular}

The tables and the diagrams above indicate an improvement for speaking class by applying LMS Google Classroom from pre-test to post-test. The score increased from 1103 in the pre-test to 1618 in the post-test. The overall students' score increased mean score from 36.7667 in the pre-test to 54.1467 in the post-test.

Table 4. The students score in teaching English using LMS Google Classroom

\begin{tabular}{cccc}
\hline Subject/ Test & $\begin{array}{c}\text { Pre-Test } \\
\text { Average }\end{array}$ & $\begin{array}{c}\text { Post-Test } \\
\text { Average }\end{array}$ & $\begin{array}{c}\text { Increasing the } \\
\text { average }\end{array}$ \\
\hline $\begin{array}{c}\text { Speaking I Average } \\
\text { Values }\end{array}$ & 46.00 & 75.62 & 29.62 \\
\hline $\begin{array}{c}\text { Listening Comprehension } \\
\text { I Average values }\end{array}$ & 48.00 & 50.54 & 2.54 \\
\hline $\begin{array}{c}\text { Reading Comprehension I } \\
\text { Average Values }\end{array}$ & 50.25 & 70.56 & 20.31 \\
\hline $\begin{array}{c}\text { Academic Writing I } \\
\text { Average Values }\end{array}$ & 48.02 & 61.09 & 13.07 \\
\hline $\begin{array}{c}\text { Grammar \& Structure I } \\
\text { Average Values }\end{array}$ & 52.12 & 68.42 & 16.30 \\
\hline
\end{tabular}

The data above indicates that teaching English using Google Classroom LMS was quite effective. However, there are various technical obstacles and student complaints, such as limited internet access, internet quota, learning facilities. The evaluation results found that of the entire English Literature study program, students who attended lectures in the network (online) used a smartphone, and most of the learning locations were in free Wi-Fi coffee shops.

The test results show an increase in student scores in learning English through the implementation of the LMS Google Classroom. Although this value is not a significant increase, it was certain that the implementation of the LMS Google Classroom could provide positive benefits in the continuity of the teaching and learning process in the Literature Study Program at the Faculty of 
Literatures and Humanities Islamic University of Makassar. Especially in the current pandemic, tactical steps are needed to anticipate the ineffective teaching and learning process problems.

Speaking I course, there is a significant increase compared to other courses. This is influenced by the creative ability of students in doing practice speaking freely and innovatively. During ELearning, students are given space to practice speaking through electronic learning models, and features such as; online presentations, free open books/ online dictionaries, and facilities for Google translate, YouTube, social media, chat, etc. Likewise, data from the results of questionnaires and interviews showed that students were not fully ready to take part in the online learning process.

The students' attitudes can be known from the distribution of questionnaires. There were 12 statements given to 30 respondents from the English Literature Study Program at the Faculty of Literature and Humanities, Islamic University of Makassar. These statements' specific aim was to know the student's attitude and perspective after joining an English online class during pandemic Covid-19. The students' answers, especially in the main statement "Teaching English by implementing Learning Management System Google Classroom at the University can effectively improve students' English competency," almost all students agree to this point. Twenty-five students agreed that this learning model could improve the students' competencies, and only one student disagrees. For TOEFL and Listening teaching, some of the students disagreed with using LMS Google Classroom, 6 students gave a negative response, and 24 agreed.

\section{Discussion}

Teaching English in the English Literature study program, Faculty of Literatures and Humanities, Islamic University of Makassar, has defined learning with an online model since the large-scale social restrictions (PSBB in Bahasa) in March 2020. Therefore, the teaching and learning process at the Faculty of Literatures has also been carried out using an online model. Technically, online learning models and tools are handed over to the lecturer who teaches the subject concerned. The test is used to measure the effectiveness of LMS Google Classroom in teaching English. A pretest is applied before treatment, and a post-test is applied after treatment. The questionnaire is given to the participant to understand the student's voice about implementing LMS Google Classroom in teaching English.

The teaching of English is not only focused on one subject, but there are several basic subjects such as vocabulary, speaking, syntax, phonology, morphology, grammar, reading, listening, and writing. Data of the Speaking test has described in finding that there is significance increasing from pre-test to post-test as the tables, and the diagrams 3 indicate an improvement for speaking class by applying LMS Google Classroom. The score increased from 1103 in the pre-test to 1618 in the posttest. It shows an increase in mean score from 36.7667 in the pre-test to 54.1467 in the post-test. ELearning is running well, especially for speaking classes. By using LMS Google Classroom in English teaching can help students to improve their English skills.

Based on Richards, (2001) approach about communicative language teaching can work well by using LMS Google Classroom in English teaching in university. Speaking class as the sample subject showed the significances score. Even though other subjects did not show the higher significances, but can be assumed that LMS Google Classroom is receptive in using as an alternative education platform in the pandemic era. Nowadays, the existence of information technology (IT) affects the education sector because teachers and students can use those techniques in communicative teaching. In the current digital era, where teaching requires using technology, including LMS, is very effective for technology class and language class (Cavus, 2015).

Teaching speaking through technological use and their features are adaptive. Speaking practice can apply not only in a conventional way like face to face in a classroom situation but also can apply in LMS Google Classroom and social media. The students can make a simple presentation class, interview job via LMS Google Classroom, discussion, debate, and many more ways of speaking 
practice. It is different from other subjects such as grammar, writing, or listening; not only online practice but these subjects maybe need some extra tutoring.

The students' attitude by implementing LMS Google Classroom in English teaching in university that almost students receptive well even though around 5-6 give a negative response. The variation of students' responses indicates their attitude toward online learning in university, and the teacher proposes the LMS Google Classroom. Some reasons rise from the students doing the online class out of the questionnaire statements such as the connectivity of internet access, miss the offline class, cannot focus if join the online class and time limit. It is difficult to change our culture from offline learning become online learning. It is happening to some students in the Islamic University of Makassar, for this situation need the government policy, institution policy, and teachers creativity in handling the online class.

The study results indicate an urgent role for the teacher in the continuity of teaching. In the previous conventional class, the teacher was only prepared to teach material and delivers it in the classroom. Meanwhile, in this online classroom situation, where the teacher has to prepare very adaptive material so that students easily accept it because it is only controlled through a monitor screen, the lecturer has a dual role in the sustainability of the class because he must ensure that all participants are ready both materially and psychologically. The teacher must be able to convince and support students in following lectures well. From the observations made, it was found that not all students accepted a learning situation like this, even though they accepted it at the end of the lecture under various conditions.

\section{CONCLUSION}

The online lecture model conducted at the Islamic University of Makassar with the LMS Google Classroom is a distance learning system. Students and lecturers do not need to meet face to face directly. The online learning system or E-Learning in English learning through the LMS Google Classroom has positively contributed to the continuity of the teaching and learning process during the Covid-19 pandemic. The students' score based on the post-test indicated that online class in teaching English using LMS Google Classroom could improve the student's competencies, and also from the questionnaire has given to the respondents show the positive attitude, it means that LMS Google Classroom can adopt in university especially in teaching English for all subjects.

It can be concluded that the LMS Google Classroom is effective in learning English in universities, especially in learning English. Nevertheless, of course, not all courses are relevant to this method. Theoretically, with the constructivism approach in this research, it can be described that there is a change in the level of student productivity that appears in the completion of course assignments, test results, and student progress in creating and innovating. These works and innovations include several students who can work independently, such as their participation in online English debates, KTI, PKM, and independent work during the lecture process with the Covid19 pandemic situation.

\section{REFERENCES}

Alessi, S. M. \& Trollip, S.R. (2001). Multimedia for Learning: Methods and Development. Massachusetts: Allyn \& Bacon.

Al Ahsan, H. R. (2019). The Effectiveness of Using Google Classroom Application to Teach Writing Skill. (Doctoral dissertation, State Islam Institute).

Ampa, A. T. (2013). Developing Multimedia Learning Materials for Speaking Skills Based on Contextual Teaching and Learning Principles. Post Graduate Program. State University of Makassar: Unpublished Dissertation.

Azhar, K. A., \& Iqbal, N. (2018). Effectiveness of Google classroom: Teachers' perceptions. Prizren Social Science Journal, 2(2), 52-66.

Bannan-Ritland, B. (2004). Web-based instruction. In A. \&. Kovalchick, Education Technology: An encyclopedia,. Santa Barbara, CA: ABC-CLIO Publication. 638-644

Bates, A., \& Poole, G. (2003). Effective teaching with technology in higher education (11th Ed.). San 
Francisco: John Wiley.

Beevers, C., McGuire, G., Sterling, G., \& Wild, D. (1995). Mathematical Ability Assesed by Computer. Computers and Education , 123-132.

Benson, P. (2001). Teaching and Reseaching Autonomy in Language Learning Malaysia LSP. Harlow: Longman.

Biffi, E. (2016). An unexpected encounter: educational science and psychoanalysis in the phenomenological pedagogy of Piero Bertolini. ENCYCLOPEDIA, XX(45), 67-81. https://doi.org/10.6092/issn.1825-8670/6325

Blumberg, P. (2019). Making Learning-Centered Teaching Work: Practical Strategies for Implementation. Stylus Publishing, LLC.

Bossio, F. (2018). Intercultural Education as a Phenomenological Paradigm of Responsibility and Care. ENCYCLOPEDIA, 22(50), 93-101.

Branch, R. (2009). Instructional design: The ADDIE Approach. Boston: Springer-Verlag US.

Bujang, A., Naho, A., \& Awang, N. (2019). The Application Of Information And Communication Technology (ICT) In Teaching And Learning: The Application Of Information And Communication Technology (ICT) In Teaching And Learning. ILKKM Journal of Medical and Health Sciences, 1(2), 1-5.

Cao, Y. (2012). A Study of Metacognitive Strategies in Web-based English Autonomous Learning. International Conference on Management and Education Innovatio. 37. IACSIT Press Singapore.

Carter, K. (2004). Online Training: What's really Working? Technology and Learning, 32-36.

Cavus, N. (2015). Distance Learning and Learning Management Systems. Procedia - Social and $\begin{array}{llll}\text { Behavioral Sciences: } & \text { ELSEVIER, }\end{array}$ https://doi.org/10.1016/j.sbspro.2015.04.611

Chamot, A. (1999). Children's learing strategies in immersion classrooms. The Modern Language Journal, 319-341.

Chang, K., Sung, Y., \& Hou, H. (2006). Web-based Tools for Designing and Developing Teaching Materials for Integration of Information Technology into Instruction. Educational Technology and Society , 139-149.

Cheng, Y. M., \& Chen, P. F. (2012). Autonomous Pedagogical Agents to E-Learning in Elementary School. Journal of Information Hiding and Multimedia Signal Processing, III (4), 2073-4212.

Chiuan Chia, C. S. (2005). Promoting independent learning through language learning and the use of IT. Educational Media International, 42(4), 317-332.

CIEL Project. (2000). Integrating Independent Language Learning: Management and Policy Considerations. CIEL.

Erstad, O. (2006). A New Direction? Digital Literacy, Student Participation and Curriculum Reform in Norway. Education and Information Technologies Journal, 415-429.

Gehart, D. (2011). The core competencies and MFT education: Practical aspects of transitioning to a learning-centered, outcome-based pedagogy. Journal of Marital and Family Therapy, 37(3), 344-354.

Ghirotto, L. (2016). Research Method and Phenomenological Pedagogy. ENCYCLOPEDIA, (45), 8294. https://doi.org/10.6092/issn.1825-8670/6326

Gilakjani, A. P. (2012). Visual, auditory, kinesthetic learning styles and their impacts on English language teaching. Journal of studies in education, 2(1), 104-113.

Gog, T. v., Rummel, N., \& Renkl, A. (2019). Learning how to solve problems by studying examples. In J. Dunlosky \& K. A. Rawson (Eds.), The Cambridge handbook of cognition and education. Cambridge University Press. 183-208).

Grunert. (1997). The Course Syllabus: A Learning-centered Approach. Bolton: Anker Publishing Company, Inc.

Hadjerrouit, S. (2010). Developing Web-based learning Resources in School Education: A Usercentered Approach. Interdisciplinary Journal of E-LEarning and LEarning Objects , 6

Hargood, C., Weal, M. J., \& Millard, D. E. (2018). The storyplaces platform: Building a web-based locative hypertext system. In Proceedings of the 29th on Hypertext and Social Media. 128135 .

Hinnon, A. (2007). Solving Errors in Writing of Graduate Students at Khon Khaen University via Web-based Instruction. Khon Khaen: Khon Khaen Univeristy. 
Horton, W. (2000). Designing web-based training. Wiley \& Sons Computer Publishing, Inc.

Hussain, D. (2011). Fostering Autonomous Learning Inside and Outside the Classroom in Language Learning. Makassar: Badan Penerbit UNM.

Keengwe, J., Onchwari, G., \& Wachira, P. (2008). Computer technology integration and student learning: Barriers and promise. Journal of science education and technology, 17(6), 560-565.

Kemp, L. (2000). Research in Teacher Education. Technology Competencies in Teacher Education. An Evaluation To Guide Implementation of Beginning Teacher Technology Competencies.

Kern, R., \& Warrschauer, M. (2000). Theory and practice of network-based language teaching ,. In M. W. Kern, Network-based language teaching: concepts and practice. New York: Cambridge University Press.

Kumrow, D., Vogt, C., \& Kazlauskas, E. (2002). The Role of Learning Strategies in Web-based Instruction. The Free Library.

Liu, H. (2013). Constructing a web-based autonomous learning model for teaching English. World Transactions on Engineering and Technology Education, 11 (4).

Ma, Y., \& Wang, L. (2012). An Effective Web-based College English Teaching Mode and Lesson Plan Design. International Conference on Education Technology and Management Engineering, 16-17.

Mahmoudi, E., Samad, A., \& Razak, N. (2012). Attitude and Students' Performance in Computer Assisted English Learning (CAELL) for Learning Vocabulary. In Procedia-Social and Behavioural Sciences 66 . 489-498.

Nguyen, D., \& Kulm, K. (2005). Using web-based practice to enhance mathematics learning and achievement. Journal of Interactive Online Learning, 1-16.

Nielsen, J. (2000). Designing Web Usability: The Practice of simplicity. New Riders Publishing.

Okmawati, M. (2020). The use of Google Classroom during pandemic. Journal of English Language Teaching, 9(2), 438-443.

Olson, T. M., Wisher, R. A. (2002). The Effectiveness of Web-Based Intstruction: An initial inquiry. The International Review of Research in Open and Distributed Learning. Athabasca University. Retrieved on December 05, 2020, from http://www.irrodl.org/index.php/irrodl/article/view/103/182

Pacheco, A. (2005). Web-based learning (WBL): A challenge for foreign language teachers. Revista Electrónica.

Paracha, Samiullah et al. (2005). Promoting Autonomous Computer Assisted Learning. Journal of Theoritical and Applied Information Technology .

Renkl, A. (2005). The Worked-Out Examples Principle in Multimedia Learning. In R. E. Mayer (Ed.), The Cambridge handbook of multimedia learning. 229-245.

.Ryder, M. (2008). Instructional Design Models. Retrieved Juny 10, 2020, from http://carbon.cudenver.edu/ mryder/itc/idmodels.html

Sa'ari, J. R., Luan, W. S., \& Roslan, S. (2005). Attitudes and perceived information technology competency among teachers. Malaysian online journal of instructional technology, 2(3), 7077 .

Saitakham, K. (2010). The Development of Web-based Instructional Model to Enhance Vocabulary Learning Ability Through Context-CLues Based Meaning Guessing Technique for the English as a Foreign Language University Students. Nakhon Ratchasima: Suranaree Univeristy of Technology.

Shaharanee, I. N. M., Jamil, J. M., \& Rodzi, S. S. M. (2016). The application of Google Classroom as a tool for teaching and learning. Journal of Telecommunication, Electronic and Computer Engineering (JTEC), 8(10), 5-8.

Smith, S. (2010). Evaluation, testing and assesment. In American Library Association, Web-based instruction: A guide for libraries. Chichago: American Library Association. 177-186.

Spratt, M., Humphreys, G., \& Chan, V. (2002). Autonomy and motivation which comes first? Language Teaching Research , 245-326.

Sri Lengkanawati, N. (2004). How Learners from Different Backgrounds Learn Foreign Language. Asian EFL Journal .

Sugiyono. (2011). Metode Penelitian Administrasi dilengkapi Metode R \& D. Bandung: Alfabeta

Suriaman, A. (2015). Strategies in promoting independent learning through self-access centre at Tadulako University. Asian EFL Journal - Professional Teaching Article.88.

Syafi'i, A. (2020). Google Classroom as learning platform in teaching writing. British (Jurnal Bahasa 
dan Sastra Inggris), 9(1), 48-64.

Wong, C. (2001). Attitudes and achievements: Comparing Computer-based and Paper-based Homework Assignments in Mathematics. Journal of Research on Technology in Education .

Yaumi, M. (2013). Prinsip-Prinsip Desain Pembelajaran. Jakarta: Kencana Media Grup.

Victoria, P. (2018). Critical Education in Paulo Freire: Education Action for Social Trasformation. ENCYCLOPEDIA, 22 (15), 37-44Sd Inpres Bangkala Ii Kota Makassar. Lentera Pendidikan : Jurnal Ilmu Tarbiyah Dan Keguruan, 2O(1), 18-30. https://doi.org/10.24252/lp.2017v20n1a2

Khanafi, I., Salafuddin, S., Abidin, M. Y., \& Khamidi, A. N. (2013). Persepsi dan Transformasi Visi dan Misi Pada Civitas Akademika Stain Pekalongan. Jurnal Penelitian, 6(2). https://doi.org/10.28918/jupe.v6i2.229

Pratiwi, Y. E., \& Sunarso, S. (2018). Peranan Musyawarah Mufakat (Bubalah) Dalam Membentuk Iklim Akademik Positif di Prodi PPKn FKIP Unila. Sosiohumaniora, 2O(3), 199. https://doi.org/10.24198/sosiohumaniora.v20i3.16254

Sudarmanto. (2018). Peranan Kepala Sekolah dalam Mewujudkan Visi Dan Misi Sekolah Menjadi Sebuah Aksi. Retrieved April 15, 2020, from https://cahayabegawan.blogspot.com/2017/o4/peranan-kepala-sekolah-dalam-mewujudkan.html

Wahyudin, W. (2018). Optimalisasi Peran Kepala Sekolah dalam Implementasi Kurikulum 2013. Jurnal Kependidikan, 6(2), 249-265. https://doi.org/10.24090/jk.v6i2.1932

Wulandari, R. Y. (2016). Implementasi supervisi manajerial pengawas sekolah dalam meningkatkan kompetensi pengelola perpustakaan. Manajer Pendidikan, 1O(2).

Yusutria, Y. (2018). Analisis Mutu Lembaga Pendidikan Berdasarkan Fungsi Manajemen di Pondok Pesantren Thawalib Padang Sumatera Barat. Ta'dib: Jurnal Pendidikan Islam, 7(2), 61-68. https://doi.org/10.29313/tjpi.v7i2.3833 